NBER WORKING PAPER SERIES

\title{
THE MAKING OF HOMO HONORATUS: FROM OMISSION TO COMMISSION
}

\author{
Michael Hallsworth \\ John A. List \\ Robert D. Metcalfe \\ Ivo Vlaev \\ Working Paper 21210 \\ http://www.nber.org/papers/w21210 \\ NATIONAL BUREAU OF ECONOMIC RESEARCH \\ 1050 Massachusetts Avenue \\ Cambridge, MA 02138 \\ May 2015
}

We would like to thank Her Majesty's Revenue and Customs, the Cabinet Office, and their officials-especially Pedro Wrobel, Nick Down, David Halpern, Jackie Simms, Lesley Titley, Matt Cole, Dawn Reade, Simon Bradford, Mike Holgate, Bob Appleton, Gordon Smith, Graham Brammer, Owain Service, and Mike Drewery. We would like to thank David Novgorodsky, Wooju Lee and Joseph Seidel for their research assistance. We would also like to thank Ara Darzi. The views expressed herein are those of the authors and do not necessarily reflect the views of the National Bureau of Economic Research. The trials were funded as part of routine administration work carried out by HM Revenue and Customs. Michael Hallsworth is currently employed by the Behavioural Insights Team.

NBER working papers are circulated for discussion and comment purposes. They have not been peerreviewed or been subject to the review by the NBER Board of Directors that accompanies official NBER publications.

(C) 2015 by Michael Hallsworth, John A. List, Robert D. Metcalfe, and Ivo Vlaev. All rights reserved. Short sections of text, not to exceed two paragraphs, may be quoted without explicit permission provided that full credit, including $(\mathcal{O}$ notice, is given to the source. 
The Making of Homo Honoratus: F̧rom Omission to Commission

Michael Hallsworth, John A. List, Robert D. Metcalfe, and Ivo Vlaev

NBER Working Paper No. 21210

May 2015

JEL No. C9,C93,H2,K0

\begin{abstract}
Framing remains one of the pillars of behavioral economics. While framing effects have been found to be quite important in the lab, what is less clear is how well evidence drawn from naturally-occurring settings conforms to received laboratory insights. We use debt obligation to the UK government as a case study to explore the 'omission bias' present in decision making with large stakes. Using a natural field experiment that generates nearly 40,000 observations, we find that repayment rates are roughly doubled when the act is reframed as one of commission rather than omission. We estimate that this reframing of the perceived nature of the action generated over $\$ 1.3$ million of new yield. We find evidence that this behavior may result from a deliberate 'omission strategy', rather than a behavioral bias, as is often assumed in the literature. Our natural field experiment highlights that behavioral economics is much more than a series of empirical exercises to quench the intellectual curiosity of academics.
\end{abstract}

Michael Hallsworth

Imperial College London

The Behavioural Insights Team

m.hallsworth11@imperial.ac.uk

John A. List

Department of Economics

University of Chicago

1126 East 59th

Chicago, IL 60637

and NBER

jlist@uchicago.edu
Robert D. Metcalfe

University of Chicago

Saieh Hall for Economics

5757 S. University Avenue

Chicago IL, 60637

rdmetc@gmail.com

Ivo Vlaev

Warwick Business School

University of Warwick

Ivo.Vlaev@wbs.ac.uk 
Day after day deceitful acts permeate our society, from rule-bending by consumers, welfare claimants, and corporate citizens, to outright fraudulent behaviours by firms and even governments themselves. While literatures have developed to explain such acts, ${ }^{1}$ officials often find it difficult to address these behaviors through traditional enforcement methods (for example, fines and prosecution). In this note, rather than explore how we can use traditional economic variables to combat dishonorable acts, we take this literature in a different direction. We leverage behavioral economics, and use 'omission bias' as a starting point. Our main hypothesis is that when considering engaging in many types of mendacious acts, many people fall short of acting honourable due to an omission strategy. If true, then we should be able to affect the prevalence of such acts by simply reframing acts of omission as acts of commission (i.e. doing nothing is an active choice).

Of course, psychologists and behavioural economists have argued for years that the manner in which a decision is presented is important (see, e.g., the endowment effect (Thaler, 1980), status quo bias (Samuelson \& Zeckhauser 1988), and differences between Hicksian surplus values (Hanemann, 1991). ${ }^{2}$ Although considerable laboratory evidence consonant with framing effects has accumulated in the literature, ${ }^{3}$ a natural inclination for many economists is to discount such results on the grounds that they reflect inexperienced subjects or maladroit designs. While work has begun to extend the empirical results to the field (see, e.g., List, 2003; 2004), there is limited evidence on first-order questions such as: can framing manipulations have important economic effects in naturally-occurring markets? ${ }^{4}$ This is not surprising in light of the difficulties associated with executing a clean test in the field.

To lend insights into both this methodological query and the importance of 'omission bias' in the field, we use as a case study repayment of debt. Our

\footnotetext{
${ }^{1}$ The economic analysis of crime began on a very high plane with the work of Beccaria and Bentham in the $18^{\text {th }}$ and $19^{\text {th }}$ centuries, but its revival in modern times dates only to 1968 , when Gary Becker's article on the economics of crime (Becker, 1968). Since then there has been an outpouring of economic work on crime in the following areas: the optimal trade-off between certainty and severity of punishment, the comparative economic properties of fines and imprisonment, the economics of law enforcement and criminal procedure, and above all the deterrent and preventive effects of criminal punishment (including capital punishment).

${ }^{2}$ Philosophers have long been interested in this area - see Singer (1979) and Steinbock (1980).

${ }^{3}$ Using lab experiments, Cox et al. (2013) find that people act more reciprocal (both positive and negative) when another's behavior results from acts of commission rather than acts of omission. They argue that the most fruitful future area of examining the omission-commission distinction is using field experiments to understand their real world importance.

${ }^{4}$ Yet, see the recent work of Fryer et al. (2012) with teachers and Hossain and List (2012) with factory workers. On dishonesty, the interested reader should see, e.g., Gneezy (2005), Sutter (2009), and Cappelen et al. (2013), who explore the prevalence and importance of dishonesty.
} 
experimental platform is the recent approach taken by Her Majesty's Revenue and Customs (the UK Government Tax Office) to debt collection. We view the collaboration with the UK Government Tax Office as representing a perfect setting for our inquiry because the experimental subjects are people who actually have failed to repay overpaid government benefits, which presents a clear opportunity to profit through acts of omission. We augment the Government's traditional repayment letter by including the following message in our 'omission to commission' letters: "Previously, we treated your lack of response as an oversight. Now, if you do not call [telephone number], we will treat this as an active choice."

Our letters were randomized across a section of the UK population who owed money in 2012. Making use of information gathered from nearly 40,000 letters, we find that in the control treatment roughly $12 \%$ of letter recipients repay their debt obligation within 30 days. This is considerably less than the repayment rates of those receiving omission messages $(\sim 23 \%)$, which almost doubled the likelihood of paying money back to the Government. The stakes in our experiment are quite large in that the 'omission to commission' treatments led to over $£ 1.2$ million (i.e. $\$ 1.8$ million) in revenue being accelerated over a 30-day period. Moreover, we estimate that the treatments ultimately led to $£ 0.88 \mathrm{~m}(\$ 1.3 \mathrm{~m})$ of new (not accelerated) yield because of the way the debts were subsequently treated. The observed treatment effects are significantly larger than treatment effects we find from providing more information on how to pay, helping recipients plan their payment, or summarizing the letter content.

Our preferred interpretation is that people believe that non-payment in the omission to commission treatment will result in greater punishment compared to nonpayment in the control treatment (see the excellent discussion in Spranca et al., 1991; DeScioli et al., 2011). This interpretation is confirmed in a companion survey, which reveals that $80 \%$ of people believe that non-payment in the omission to commission treatment will result in greater punishment compared to non-payment in the control treatment. Our data, therefore, suggest that agents responding to the commission message are rational in the sense that they anticipate greater punishment if they do not act honestly. This is at odds with the traditional 'omission bias' literature, which interprets omission as a bias rather than a strategic choice. In this way, an 'omission strategy' can be part of an equilibrium explaining why such framing manipulations work. 
The remainder of our study proceeds as follows. The next section details the experimental design. Section II summarizes the results. Section III concludes.

\section{Field Experimental Design}

While there are many forms of dishonesty, we focus our case study on the interaction between individuals and authorities. There are many instances in which individuals are required to comply with government requests to give an honest and accurate report of their circumstances. We take the example of the disbursement of government benefits. The US government offers over 1,000 different benefits programs, and total transfer receipts to individuals from governments in the US stood at \$2.25 trillion in 2011 (Benefits.gov, 2013; Bureau of Economic Analysis, 2013). Many of these benefits require certain conditions to be met, and require the recipient to notify the disburser if this ceases to be the case. There is thus the potential for a recipient to fail to make such a notification, and thereby profit by omission. ${ }^{5}$ This potential also exists in the UK benefits system, and therefore the UK represents a fertile ground to explore the effect of omission and commission.

In this spirit, we address a particular compliance challenge: collecting overpaid Tax Credits, a form of benefit provided by the UK government. ${ }^{6}$ Reasons why a recipient may be paid too much through UK Tax Credits include: a failure to notify the authorities of a change in the recipient's situation, providing incorrect information, or a failure to renew credits on time. ${ }^{7}$ If this happens, then the UK government has a duty to reclaim the overpaid Tax Credits, since they constitute a debt. Individuals receive an initial statement of the debt; if they do not respond to this statement, then they are sent targeted letters requesting payment, followed by further enforcement actions, if appropriate. ${ }^{8}$

\footnotetext{
${ }^{5}$ For example, in $201210.5 \%$ of Unemployment Insurance benefits were overpaid (some owing to agency error), amounting to $\$ 4.5$ billion in total. Only $21 \%$ of these overpayments were recovered (United States Department of Labor, 2013). Meanwhile, the cumulative amount owed through social security payments nearly doubled between 2001 and 2011, to stand at $\$ 7.3$ billion (United States Government Accountability Office 2012). In addition, improper payments represented $10.1 \%$ of Medicare spending in FY 2013, amounting to \$36 billion. (Department of Health and Human Services, 2013, 165). It is worth noting that Thurman (1991) offers evidence that omission bias is present in tax evasion, which has several similarities to the inappropriate receipt of government benefits.

${ }^{6}$ Tax credits come in two main forms: Child Tax Credit, awarded to support the raising of children, and Working Tax Credit, paid to those who are in work but have a low income. For more information, see https://www.gov.uk/child-tax-credit

${ }^{7}$ http://www.hmrc.gov.uk/taxcredits/things-go-wrong/overpayments/how-happened.htm

8 The enforcement actions include telephone calls and personal visits from an HMRC officer. If no contact can be made, or the benefit recipient refuses to pay, then HMRC may: refer the debt to a private
} 


\section{Methodology}

As our control, we employ the original letter typically used by the UK Government Tax Office - see Appendix. In this way, the control condition is essentially a form letter that includes basic information about the size of debt and how to pay. The experimental treatment letters were identical to the control apart from inclusion of various short messages (see Appendix for both the control and the Collective Omission to Commission letters). The first, and most important, departure from the control letter is our omission to commission letters. In these cases, we simply add the following to the control, as can be seen in the Appendix: "Previously, we treated your lack of response as an oversight. Now, if you do not call [telephone number], we will treat this as an active choice."

Constructing any message clearly involves making many choices about features such as tone, vocabulary, and length. However, in this situation one aspect of the test messages in particular is likely to affect their impact: the nature of the sender (Dolan et al., 2012). The 'omission strategy' is based on anticipated blame, and the salience of this blame is likely to vary according to its source. In this situation, there are two overlapping sources, since the letter is addressed from both an organization (i.e. the UK tax office) and an individual within that organization (i.e. a specific collector). ${ }^{9} \quad$ As such, there is a case for examining whether emphasizing the individual or the collective influences compliance. While this specific issue is rarely examined, Tausczik and Pennebaker (2010) note that there is much evidence that lower status speakers make greater use of the first person singular "I", whereas higher status speakers use the first person plural "we" more often. In addition, studies such as Bargh (2006) show that priming with collective (as opposed to singular) pronouns can increase levels of demonstrated altruism. Therefore, we introduce a subordinate hypothesis: Individuals who receive a message, at the point of decision, that states that non-compliance will be an act of commission will be more likely to comply if the sender is framed as a collective, rather than an individual.

debt collection agency; seek to remove it automatically from payrolls; or consider seizing goods to recoup the amount owed. A summary of the process can be found at: http://www.revenuebenefits.org.uk/tax-credits/guidance/how-to-deal-with-hmrc/dealing-with-debt/. We discuss the particular actions applied to these debts later in the article.

${ }^{9}$ The name of the individual sender has been excluded from the letter examples in the Appendix. 
Two messages were constructed to test this hypothesis. The first was: "Previously, I treated your lack of response as an oversight. Now, if you do not call [telephone number], I will treat this as an active choice" (we call this "Individual Omission to Commission'). The second was: "Previously, we treated your lack of response as an oversight. Now, if you do not call [telephone number], we will treat this as an active choice" ('Collective Omission to Commission'). Note that the two messages are identical except for the pronouns; by limiting the changes in this way, we can isolate the effect of the individual/collective framing.

We also took the opportunity to compare countering the omission strategy with an alternative approach for increasing compliance, based on offering additional help and lowering perceived barriers to resolving the recipient's debt situation. This more "customer focused" approach has been discussed extensively as a means of creating a good relationship between tax authority and citizen - which in turn has been found to boost voluntary compliance (Kirchler, 2007; Braithwaite, 2003; Smith, 1992). There is some field experimental evidence from the UK that messages of this kind can raise tax compliance (Hasseldine et al., 2007; Hallsworth et al., 2014).

In our field experiment, these additional letters provided more information about call centre opening times (denoted 'Opportunity'), pointed out that the tax authority was attempting to resolve the issue (denoted 'Reciprocity'), suggested making a plan to call the tax authority (denoted 'Planning'), and provided a summary box of the main points in the letter (denoted 'Summary Box') (see Table 1). These other treatments provide a reference effect size and place our main treatment effects in perspective.

The letters requesting payment of debts included in our field experiment were issued in January 2012. The experimental sample of 38,800 cases consisted of all debtors for whom the outstanding amount could not be recovered via payroll deductions. We calculated that an equal allocation amongst the seven messages detailed above would allow us to detect a $2.7 \%$ ATE with $80 \%$ power, which is similar to the smaller effects obtained by Hasseldine et al. (2007) and Hallsworth et al. (2014). Individual cases were randomized using the random number function in SAS, with no blocking and roughly equal allocation to each group. Letters were then issued over five sequential days. It was not possible to randomize the issue of letters across these days. Instead, letters were issued in tranches organised by debt size - 
since the randomisation was successful, this resulted in equal proportions of each letter being issued each day (see Table 1).

\section{Field Experimental Results}

We first check the balance of the randomization on the background variables. Table 2 shows the regressions on these variables, with the treatment groups as independent variables and the reference group as the control group. Regressions (I) to (VI) show that there are no significant differences between control and treatment groups on four covariates available to us: gross income for the tax year; log gross income; gender; and (female) title. We also test the latter four regressions using a chisquared test and find similar negligible differences.

Our main results are contained in Table 3, which presents the marginal effects from a logit regression where the dependent variable is whether the recipient made a payment within 30 days of being sent the letter. Thirty days represents the last point at which we can be confident that individuals had not received the subsequent letter asking for payment (which did not form part of this experiment). Around 12\% of recipients in our control treatment made such a payment within 30 days.

Regression (I) is the basic specification, with the treatment groups as the independent variables. The 'Reciprocity', 'Planning', and 'Summary box' treatments do not have a significant effect on repayment rates. The 'Opportunity' treatment produced a $2.2 \%$ increase in payments. The effect in comparison to the control group is an $18.5 \%$ (0.06 standard deviations) effect size.

In terms of the omission to commission messages, the 'Collective Omission to Commission' group created an 11.2 percentage point increase in payment rates. This is equivalent to a $94.1 \%$ (0.33 standard deviations) treatment effect size. Moreover, the 'Individual Omission to Commission' group produced a 10.9 percentage point increase. This is equivalent to a $91.6 \%$ (0.32 standard deviations) treatment effect size. These results are not statistically significantly different from each other, which does not support our secondary hypothesis. However, they are significantly different from the other treatment effects and the control at conventional significance levels, confirming our primary hypothesis $(\mathrm{p}<0.001)$.

Regression (II) in Table 3 includes the individual's gross income for that year and their gender (dummy being male). Importantly, when we include these variables the coefficients on our treatments do not change. As far as the observables, we find 
that individuals with higher incomes are more likely to repay the Tax Credits. For each pound sterling that someone earns, they are $0.0002 \%$ more likely to pay the tax back within 30 days. To place the 11.2 percentage increase found above for "Collective Omission to Commission" in context, we would have to raise incomes by $£ 50,000$ to obtain the same effect.

We find that men are five percentage points less likely than women to repay their tax credits. This result accords with the relatively limited evidence on gender and tax compliance (Kastlunger et al., 2010; Jackson and Milliron, 1986). Regression (III) interacts the income and gender variables with the six treatment variables. The interactions are neither large nor statistically significant.

Table 4 examines the impact of the treatments on the payment date. This dependent variable is different from that presented in Table 3, which represented whether the individual had made a payment within 30 days of the letter being issued. The dependent variable in this case is 'day of payment,' which is a continuous variable measuring the actual numbers of days until the first payment is made by the individual. In this way, it potentially provides more information than Table 3 , since it extends beyond the initial 30 day period. Any person who still had not paid at the time we extracted the data received the maximum value of 412 days.

Regression (I) in Table 4 shows that the omission to commission groups pay much earlier than the recipients in the control and the other treatment groups. The "Collective Omission to Commission" group made their payment 22 days earlier than the control, and the "Individual Omission to Commission" group made their payment 18 days earlier than the control. In comparison to the control, the effect sizes are $9 \%$ (0.13 standard deviations) and 7.3\% (0.11 standard deviations), respectively. Surprisingly, the 'Planning' treatment group made payments seven days earlier than the control group. This is interesting: it implies that the planning message had an initial effect on payments that was not sustained over the longer term. ${ }^{10}$

Regression (II) in Table 4 introduces income and gender. Consistent with Table 3, we find that individuals with higher gross incomes are more likely to repay the government - with each extra pound sterling of income they are likely to pay it back 0.003 days quicker. Moreover, men wait 40 days longer than women to make a

\footnotetext{
${ }^{10}$ A comparison with Table 3 shows that overall the Planning letter did not lead to a higher payment rate at 30 days. However, it did mean that people paid earlier on average, and (since the randomisation is robust) it is very likely that is because of different behavior within the first thirty days.
} 
payment. Regression (III) interacts the treatment variables with both income and gender. In contrast to the previous Table, we find three significant interactions. Those with higher gross incomes who receive either the 'Planning' or 'Collective Omission to Commission' treatment take longer to pay than those with lower incomes. In addition, we find that men who receive the 'Collective Omission to Commission' treatment take considerably longer to pay than women from that same treatment group.

Using the estimates from regression (I) Table 3 we can provide an estimate of the benefits from this study. First, we can estimate the accelerated yield at 30 days. The control group in the first 30 days paid $£ 602,344$ back to the government. The 'Collective Omission to Commission' group paid $£ 1,351,414$ in the first 30 days and the 'Individual Omission to Commission' group paid $£ 1,120,331$ in the first 30 days the gross marginal yield was therefore around $£ 1.27$ million. ${ }^{11}$

Second, we can estimate the total additional (rather than accelerated) yield. To do this, we first identify the debts with a value of less than $£ 3,500$. Debts above this amount were sent for enforcement action that consisted of seizure of goods, and therefore any gains in this group are likely to consist of accelerated revenue only. However, debts below this amount were subjected only to a series of letters, which were completed within 80 days after the trial began. Therefore, any marginal gains that still existed at this end point represent additional (rather than accelerated) yield. ${ }^{12}$ At this time, the new marginal yield on sub-£3,500 debts was $£ 512,604$ ('Collective Omission to Commission') and $£ 366,920$ ('Individual Omission to Commission') the aggregated new marginal yield was $£ 879,525 .{ }^{13}$ It should be noted that the additional marginal cost to the government from this intervention was effectively zero, since these letters would have been sent regardless.

\section{Discussion}

Economic theory is consequentialist: utility is determined solely by final outcomes. Yet, there are important cases where the actions that result in those final outcomes are important. For example, we judge people less harshly if they withhold

\footnotetext{
${ }^{11}$ These calculations are made by multiplying the absolute treatment effect per group by the number of individuals in each group and the amount of debt in each group.

${ }^{12}$ No further enforcement action was planned to take place after the data period we can observe. To the best of our knowledge none did take place, but we cannot guarantee this is the case.

${ }^{13}$ At 80 days the absolute treatment effects of 'Collective Omission to Commission' and 'Individual Omission to Commission' were $8.8 \%$ and $7.6 \%$ respectively.
} 
an antidote from someone who has been poisoned than if they poison someone, even though the consequences are the same (Cushman et al., 2006). This type of behavior, and related examples such as the Trolley problem and the Vaccination problem, have been categorized as an 'omission bias.'

To more deeply explore whether indeed our experimental results are a bias or a result of strategic thinking, we complement our natural field experiment with an online survey. Using an online survey platform in April 2015, we presented a national sample of 250 UK citizens, who were previously or currently in receipt of tax credits, with two different scenarios. The 'control' scenario involved receiving the control letter ${ }^{14}$ while the 'omission' scenario featured the omission to commission letter. ${ }^{15}$ The order in which participants saw these scenarios was randomised.

Participants were then asked: "Of these two scenarios, which would lead to a more severe punishment if you did not respond to the letter?" We find that $80 \%$ choose the omission scenario. ${ }^{16}$ Our results are consonant with the notion that our natural field experiment is revealing an omission strategy, rather than a bias: knowing

\footnotetext{
${ }^{14}$ This read as follows: "Imagine that you have been paid too much in Tax Credits by the government. The tax authority sends you a letter asking for you to repay what you owe, but you do not respond. The tax authority then sends you another letter, which contains the statement: "We told you recently that you were paid too much through your tax credits. Our records show you have not been in touch about this. Please call 08453021421 now."

15 "Imagine that you have been paid too much in Tax Credits by the government. The tax authority sends you a letter asking for you to repay what you owe, but you do not respond. The tax authority then sends you another letter, which contains the statement: "We told you recently that you were paid too much through your tax credits. Our records show you have not been in touch about this. Previously, we treated your lack of response as an oversight. Now, if you do not call 0845302 1421, we will treat this as an active choice."

${ }^{16}$ To be robust, we used two versions of this omission statement, in order to test a subordinate hypothesis about perceived levels of punishment arising from the "we will treat" phrasing. The message includes the phrase "we will treat this as an active choice" (emphasis added). Therefore, it could be argued that these results simply show the effect of a signal that punishment is likely to occur; in this analysis, there is no effect from the omission element as such. In order to address this point, we included a "non-threat" variant of the omission scenario. This was identical to the one above, but with the following wording: "We told you recently that you were paid too much through your tax credits. Our records show you have not been in touch about this. Previously, your lack of response may have been an oversight. Now, if you do not call 0845302 1421, this will be an active choice." This version therefore lacked any signal of punishment, but retained the omission element. Participants were randomly allocated to see either version of the omission statement. As well as being asked to choose whether the control or (either) omission scenario would result in more punishment, they were also asked: "How severe do you think the punishment would be? (Please give your answer out of 10, where 1 means no action and 10 the maximum penalty possible.)" The results showed that $78 \%$ of those viewing the standard omission statement rated it as producing more severe punishment, compared to $81 \%$ of those viewing the "non-threat" version (not significant at the ten per cent level) The mean severity of punishment scores were 6.47 for the standard omission version and 6.79 for the non-threat omission version (not significant at the ten per cent level). These results suggest that the results from the field experiment do not simply reflect a straightforward reaction to perceptions of increased punishment.
} 
that we blame individuals less if a bad outcome ensues because they act than if they do not act, people are more likely to behave dishonestly when they can use omission. When the omission is presented as commission, participants are significantly more likely to act honestly and repay their debt to the government. In other words, if given the chance, people will select an omission option because they think they will be judged less harshly by others as a result of acting dishonestly. Therefore, in some instances it may be more appropriate to refer to the effect as an omission strategy, rather than an omission bias (see also Descioli et al., 2011). We believe that our results are the first to show that messages explicitly aimed at countering this omission strategy are effective at influencing behavior in naturally occurring markets.

From a policy perspective, the omission strategy suggests that policymakers should first examine whether they are creating services or policies that introduce the opportunities for people to exploit omission options - and eliminate those opportunities (Mazar \& Hawkins, 2015). In addition, they should consider the broad set of insights gained from lab experiments on the importance of framing. These experiments revealed an important effect that might happen in markets; our field experiment showed that this effect actually does occur in the field, and is important enough to influence high stakes allocations. 


\section{References}

Albrecht, W. Steve, Chad Albrecht and Conan C. Albrecht. 2008. "Current Trends in Fraud and its Detection." Information Security Journal: A Global Perspective, 17 (1): 212.

Bargh, John A. 2006. "What Have We Been Priming All These Years? On The Development, Mechanisms, and Ecology of Nonconscious Social Behavior." European Journal of Social Psychology, 36 (2): 147-168.

Becker, Gary S. 1968. "Crime and Punishment: An Economic Approach." Journal of Political Economy, 76: 169-217.

Benefits.gov. 2013. "Overview." http://www.benefits.gov/about-us/overview (accessed 6th May 2013).

Braithwaite, Valerie A. 2003. Taxing Democracy: Understanding Tax Avoidance and Evasion. Aldershot, UK: Ashgate Publishing Limited.

Bureau of Economic Analysis. 2013. "SA35 Personal current transfer receipts." http://www.bea.gov/itable/ (accessed 6th May 2013).

Cappelen, Alexander W., Erik Ø Sørensen, and Bertil Tungodden. 2013. "When do we lie?" Journal of Economic Behavior \& Organization, 93: 258-265.

Cox, James C., Maros Servatka, and Radovan Vadovic. 2013. "Status Quo Effects in Fairness Games: Reciprocal Responses to Acts of Commission vs. Acts of Omission." Working paper.

Cushman, Fiery, Liane Young and Marc Hauser. 2006. "The Role of Conscious Reasoning and Intuition in Moral Judgment: Testing Three Principles of Harm.” Psychological Science, 17 (12): 1082-1089.

Department of Health and Human Services. 2013. "Agency Final Report." http://www.hhs.gov/afr/2013-hhs-agency-financial-report.pdf.

Derrig, Richard A. 2002. "Insurance Fraud.” Journal of Risk and Insurance, 69 (3): 271287.

DeScioli, Peter, John Christner and Robert Kurzban. 2011. "The Omission Strategy." Psychological Science, 22(4): 442-446.

Dolan, Paul, Michael Hallsworth, David Halpern, Dominic King, Robert Metcalfe and Ivo Vlaev. 2012. "Influencing Behaviour: The Mindspace Way." Journal of Economic Psychology, 33 (1): 264-277.

Fryer, Roland G., Steven D. Levitt, John A. List, and Sally Sadoff. 2012. "Enhancing the Efficacy of Teacher Incentives through Loss Aversion: A Field Experiment.” NBER Working Paper No. 18237.

Gneezy, Uri. 2005. "Deception: The Role of Consequences." American Economic Review, 95 (1): 384-394. 
Hallsworth, Michael, John A. List, Robert Metcalfe and Ivo Vlaev. 2014. "The Behaviouralist as Tax Collector: Using Natural Field Experiments to Enhance Tax Compliance.” NBER Working Paper No. 20007.

Hanemann, W. Michael. 1991. "Willingness to Pay and Willingness to Accept: How Much Can They Differ?" American Economic Review, 81 (3): 635-647.

Hasseldine, John, Peggy Hite, Simon James and Marika Toumi. 2007. "Persuasive Communications: Tax Compliance Enforcement Strategies for Sole Proprietors." Contemporary Accounting Research, 24 (1): 171-194.

Hossain, Tanjim, and John A. List. 2012. "The Behavioralist Visits The Factory: Increasing Productivity Using Simple Framing Manipulations." Management Science, 58 (12): 2151-2167.

Jackson, Better R., and Valerie C. Milliron. 1986. "Tax Compliance Research: Findings, Problems, and Prospects" Journal of Accounting Literature, 5: 125-65.

Kirchler, Erich. 2007. The Economic Psychology of Tax Behavior. Cambridge University Press.

Kastlunger, Barbara, Stefan G. Dressler, Erich Kirchler, Luigi Mittone, and Martin Voracek. 2010. "Sex Differences in Tax Compliance: Differentiating Between Demographic Sex, Gender-Role Orientation, and Prenatal Masculinization (2D: 4D)." Journal of Economic Psychology, 31 (4): 542-552.

List, John. A. 2003. "Does Market Experience Eliminate Market Anomalies?" Quarterly Journal of Economics, 118 (1), 41-72.

List, John. A. 2004. "Neoclassical theory versus prospect theory: Evidence from the marketplace." Econometrica, 72 (2), 615-625.

Mazar, Nina and Scott A. Hawkins. 2015. "Choice Architecture in Conflicts of Interest: Defaults as Physical and Psychological Barriers to (Dis)honesty." Journal of Experimental Social Psychology, 59: 113-117.

Samuelson, William and Richard Zeckhauser. 1988. "Status Quo Bias in Decision Making." Journal of Risk and Uncertainty, 1 (1): 7-59.

Singer, Peter. 1979. Practical Ethics. Cambridge University Press.

Smith, Kent W. 1992. "Reciprocity and Fairness: Positive Incentives for Tax Compliance." In: Why People Pay Taxes: Tax Compliance and Enforcement, edited by Joel Slemrod Ann Arbor: University of Michigan Press.

Spranca, Mark, Elisa Minsk, and Jonathan Baron. 1991. "Omission and commission in judgment and choice.” Journal of Experimental Social Psychology, 27: 76-105.

Steinbock, Bonnie. 1980. (Ed.) Killing and letting die. Prentice Hall.

Sutter, Matthias. 2009. "Deception Through Telling The Truth?! Experimental Evidence From Individuals And Teams." The Economic Journal, 119: 47-60. 
Tausczik, Yla R. and James W. Pennebaker. 2010. "The Psychological Meaning of Words: LIWC and Computerized Text Analysis Methods." Journal of Language and Social Psychology, 29 (1): 24-54.

Thaler, Richard. 1980. "Toward a Positive Theory of Consumer Choice." Journal of Economic Behaviour and Organization, 1: 39-60.

Thurman, Quint C. 1991. "Taxpayer Noncompliance and General Prevention: An Expansion of the Deterrence Model." Public Finance 46, no. 2 (1991): 289-98.

United States Department of Labor. 2013. "2012 Calendar Year Data." Available at http://www.dol.gov/dol/maps/xls/2012-CalendarYear.xls (accessed April 11 2015).

United States Government Accountability Office. 2012. "Supplemental Security Income: SSA Has Taken Steps to Prevent and Detect Overpayments, but Additional Actions Could be taken to Improve Oversight." Report to Congressional Requesters. http://www.gao.gov/assets/660/650902.pdf.

Vitell, Scott J. 2003. "Consumer Ethics Research: Review, Synthesis and Suggestions for the Future." Journal of Business Ethics, 43 (1-2): 33-47.

Wibral, Matthias, Thomas Dohmen, Dietrich Klingmüller, Bernd Weber and Armin Falk. 2012. "Testosterone Administration Reduces Lying in Men." PLoS ONE, 7 (10): e46774. 
Table 1: Date of issue of Tax Credit letters, by letter

\begin{tabular}{|c|c|c|c|c|c|c|c|}
\hline \multirow[t]{3}{*}{ Group } & \multirow[t]{3}{*}{ Phrase } & \multicolumn{4}{|l|}{ Date of issue } & & \multirow[t]{3}{*}{ Total } \\
\hline & & $\begin{array}{l}05 / 01 / 12 \\
\text { Size of debt }\end{array}$ & $06 / 01 / 12$ & 09/01/12 & $10 / 01 / 12$ & 11/01/12 & \\
\hline & & $>£ 1500$ & $\begin{array}{l}£ 850 \leq \\
£ 1499\end{array}$ & $\begin{array}{l}£ 550 \leq \\
£ 849\end{array}$ & $£ 350 \leq £ 549$ & $<£ 350$ & \\
\hline 1. Control & & 1158 & 1107 & 1005 & 1122 & 1269 & 5661 \\
\hline 2. Reciprocity & $\begin{array}{l}\text { Please call [telephone number] now. We are offering to } \\
\text { help sort this out. All you have to do is call. }\end{array}$ & 1185 & 1092 & 994 & 1049 & 1204 & 5524 \\
\hline 3. Planning & $\begin{array}{l}\text { Please choose one day this week. Please choose a time } \\
\text { that day. Promise yourself to call [telephone number] }\end{array}$ & & & & & & \\
\hline 4. Summary & $\begin{array}{l}\text { then. } \\
\text { Tax Credits overpaid } \\
\text { Payment plan available } \\
\text { [telephone number] }\end{array}$ & 1138 & 1036 & 1000 & 1048 & 1213 & 5435 \\
\hline & [placed at end of letter] & 1170 & 1095 & 1098 & 1051 & 1207 & 5621 \\
\hline 5. Opportunity & $\begin{array}{l}\text { Please call [telephone number] now. We keep our lines } \\
\text { open every day: } \\
\text { Monday to Friday 08:00 - 20:00 } \\
\text { Saturday 08:00 - 16:00 } \\
\text { Sunday 10:00 - 16:00 }\end{array}$ & & & & & & \\
\hline & We are waiting for your call today. & 1149 & 1081 & 1038 & 1088 & 1263 & 5619 \\
\hline $\begin{array}{l}\text { 6. Collective } \\
\text { Omission to }\end{array}$ & $\begin{array}{l}\text { Previously, we treated your lack of response as an } \\
\text { oversight. Now, if you do not call [telephone number], }\end{array}$ & & & & & & \\
\hline $\begin{array}{l}\text { Commission } \\
\text { 7. Individual }\end{array}$ & $\begin{array}{l}\text { we will treat this as an active choice. } \\
\text { Previously, I treated your lack of response as an }\end{array}$ & 1327 & 1459 & 1275 & 1258 & 1421 & 6740 \\
\hline Omission to & $\begin{array}{l}\text { Previously, I treated your lack of response as an } \\
\text { oversight. Now, if you do not call [telephone number], }\end{array}$ & & & & & & \\
\hline Commission & I will treat this as an active choice. & 1193 & 1088 & 991 & 1088 & 1232 & 5592 \\
\hline Total & & 8,320 & 7,958 & 7,401 & 7,704 & 8,809 & \\
\hline
\end{tabular}


$\underline{\text { Table 2: Balance checks on the randomization }}$

\begin{tabular}{|c|c|c|c|c|c|c|}
\hline & $\begin{array}{c}\text { (I) } \\
\text { OLS } \\
\text { Income }\end{array}$ & $\begin{array}{c}\text { (II) } \\
\text { OLS } \\
\text { Ln(Income) }\end{array}$ & $\begin{array}{l}\text { (III) } \\
\text { Logit } \\
\text { Male }\end{array}$ & $\begin{array}{l}\text { (IV) } \\
\text { Logit } \\
\text { Mrs }\end{array}$ & $\begin{array}{l}(\mathrm{V}) \\
\text { Logit } \\
\text { Miss }\end{array}$ & $\begin{array}{l}\text { (VI) } \\
\text { Logit } \\
\text { Ms }\end{array}$ \\
\hline Reciprocity & $\begin{array}{c}-97.297 \\
(115.061)\end{array}$ & $\begin{array}{l}-0.006 \\
(0.007)\end{array}$ & $\begin{array}{l}-0.005 \\
(0.009)\end{array}$ & $\begin{array}{c}0.014 \\
(0.009)\end{array}$ & $\begin{array}{l}-0.009 \\
(0.008)\end{array}$ & $\begin{array}{c}0.001 \\
(0.005)\end{array}$ \\
\hline Planning & $\begin{array}{c}43.414 \\
(114.912)\end{array}$ & $\begin{array}{c}0.005 \\
(0.007)\end{array}$ & $\begin{array}{l}-0.005 \\
(0.009)\end{array}$ & $\begin{array}{c}0.007 \\
(0.009)\end{array}$ & $\begin{array}{c}-0.004 \\
(0.009)\end{array}$ & $\begin{array}{c}0.002 \\
(0.005)\end{array}$ \\
\hline Summary box & $\begin{array}{l}-139.487 \\
(114.732)\end{array}$ & $\begin{array}{l}-0.009 \\
(0.007)\end{array}$ & $\begin{array}{c}0.001 \\
(0.009)\end{array}$ & $\begin{array}{c}0.007 \\
(0.009)\end{array}$ & $\begin{array}{l}-0.008 \\
(0.008)\end{array}$ & $\begin{array}{c}0.000 \\
(0.005)\end{array}$ \\
\hline Opportunity & $\begin{array}{l}-160.101 \\
(114.308)\end{array}$ & $\begin{array}{c}-0.007 \\
(0.007)\end{array}$ & $\begin{array}{l}-0.009 \\
(0.009)\end{array}$ & $\begin{array}{c}0.012 \\
(0.009)\end{array}$ & $\begin{array}{c}0.004 \\
(0.009)\end{array}$ & $\begin{array}{l}-0.006 \\
(0.005)\end{array}$ \\
\hline $\begin{array}{l}\text { Collective } \\
\text { Omission to } \\
\text { Commission }\end{array}$ & $\begin{array}{c}91.192 \\
(110.854)\end{array}$ & $\begin{array}{c}0.006 \\
(0.007)\end{array}$ & $\begin{array}{c}0.004 \\
(0.008)\end{array}$ & $\begin{array}{l}-0.001 \\
(0.009)\end{array}$ & $\begin{array}{c}-0.002 \\
(0.008)\end{array}$ & $\begin{array}{c}-0.001 \\
(0.005)\end{array}$ \\
\hline $\begin{array}{l}\text { Individual } \\
\text { Omission to } \\
\text { Commission }\end{array}$ & $\begin{array}{c}22.036 \\
(115.188)\end{array}$ & $\begin{array}{c}0.002 \\
(0.007)\end{array}$ & $\begin{array}{c}0.004 \\
(0.009)\end{array}$ & $\begin{array}{c}0.006 \\
(0.009)\end{array}$ & $\begin{array}{l}-0.006 \\
(0.009)\end{array}$ & $\begin{array}{c}-0.003 \\
(0.005)\end{array}$ \\
\hline $\mathrm{N}$ & 38,097 & 38,097 & 38,290 & 38,290 & 38,290 & 38,290 \\
\hline $\mathrm{R}^{2}$ & 0.0002 & 0.0002 & 0.0002 & 0.0002 & 0.0002 & 0.0002 \\
\hline
\end{tabular}

Notes: Standard errors in parentheses. 
Table 3: Marginal effects of letter treatments on payment rates within first 30 days

\begin{tabular}{|c|c|c|c|}
\hline & $\begin{array}{c}\text { (I) } \\
\text { Logit } \\
\text { Paid in } 30 \text { days }\end{array}$ & $\begin{array}{c}\text { (II) } \\
\text { Logit } \\
\text { Paid in } 30 \text { days }\end{array}$ & $\begin{array}{c}\text { (III) } \\
\text { Logit } \\
\text { Paid in } 30 \text { days }\end{array}$ \\
\hline \multirow[t]{2}{*}{ Reciprocity } & 0.011 & 0.011 & 0.017 \\
\hline & $(0.008)$ & $(0.008)$ & $(0.022)$ \\
\hline \multirow[t]{2}{*}{ Planning } & 0.008 & 0.008 & 0.032 \\
\hline & $(0.008)$ & $(0.008)$ & $(0.024)$ \\
\hline \multirow[t]{2}{*}{ Summary box } & 0.005 & 0.005 & 0.024 \\
\hline & $(0.008)$ & $(0.008)$ & $(0.023)$ \\
\hline Opportunity & $\begin{array}{c}0.022 * * * \\
(0.008)\end{array}$ & $\begin{array}{c}0.022 * * * \\
(0.008)\end{array}$ & $\begin{array}{c}0.029 \\
(0.023)\end{array}$ \\
\hline \multirow[t]{2}{*}{$\begin{array}{l}\text { Collective Omission to } \\
\text { Commission }\end{array}$} & $0.112 * * *$ & $0.108 * * *$ & $0.147 * * *$ \\
\hline & $(0.009)$ & $(0.009)$ & $(0.027)$ \\
\hline \multirow[t]{2}{*}{$\begin{array}{l}\text { Individual Omission to } \\
\text { Commission }\end{array}$} & $0.109 * * *$ & $0.109 * * *$ & $0.104 * * *$ \\
\hline & $(0.009)$ & $(0.009)$ & $(0.026)$ \\
\hline Income & & $\begin{array}{c}2.98 \mathrm{e}-06 * * * \\
(0.000)\end{array}$ & $\begin{array}{c}3.65 \mathrm{e}-06 * * * \\
(0.000)\end{array}$ \\
\hline Male & & $\begin{array}{c}-0.050 * * * \\
(0.004)\end{array}$ & $\begin{array}{c}-0.047 * * * \\
(0.011)\end{array}$ \\
\hline Reciprocity * Income & & & $\begin{array}{c}-5.38 \mathrm{e}-07 \\
(0.000)\end{array}$ \\
\hline Planning * Income & & & $\begin{array}{c}-1.53 \mathrm{e}-06 \\
(0.000)\end{array}$ \\
\hline Summary box $*$ Income & & & $\begin{array}{c}-1.06 \mathrm{e}-06 \\
(0.000)\end{array}$ \\
\hline Opportunity $*$ Income & & & $\begin{array}{l}-4.93 \mathrm{e}-07 \\
(0.000)\end{array}$ \\
\hline \multirow{2}{*}{$\begin{array}{l}\text { Collective Commission * } \\
\text { Income }\end{array}$} & & & $-1.49 \mathrm{e}-06$ \\
\hline & & & $(0.000)$ \\
\hline \multirow{2}{*}{$\begin{array}{l}\text { Individual Commission * } \\
\text { Income }\end{array}$} & & & $4.69 \mathrm{e}-07$ \\
\hline & & & $(0.000)$ \\
\hline Reciprocity * Male & & & $\begin{array}{c}0.011 \\
(0.018)\end{array}$ \\
\hline Planning * Male & & & $\begin{array}{c}0.008 \\
(0.018)\end{array}$ \\
\hline Summary box * Male & & & $\begin{array}{l}-0.004 \\
(0.017)\end{array}$ \\
\hline Opportunity $*$ Male & & & $\begin{array}{c}0.007 \\
(0.018)\end{array}$ \\
\hline Collective Commission $*$ & & & -0.014 \\
\hline Male & & & $(0.015)$ \\
\hline \multirow{2}{*}{$\begin{array}{l}\text { Individual Commission * } \\
\text { Male }\end{array}$} & & & -0.015 \\
\hline & & & $(0.015)$ \\
\hline $\mathrm{N}$ & 38290 & 38097 & 38097 \\
\hline $\mathrm{R}^{2}$ & 0.02 & 0.02 & 0.02 \\
\hline
\end{tabular}


$\underline{\text { Table 4: OLS regressions predicting day of payment }}$

\begin{tabular}{|c|c|c|c|}
\hline & $\begin{array}{c}\text { (I) } \\
\text { Day of } \\
\text { payment }\end{array}$ & $\begin{array}{c}\text { (II) } \\
\text { Day of } \\
\text { payment }\end{array}$ & $\begin{array}{c}\text { (III) } \\
\text { Day of } \\
\text { payment }\end{array}$ \\
\hline \multirow[t]{2}{*}{ Reciprocity } & -5.398 & -5.407 & -7.104 \\
\hline & $(3.379)$ & $(3.344)$ & $(9.580)$ \\
\hline Planning & $\begin{array}{c}-7.170 * * \\
(3.372)\end{array}$ & $\begin{array}{c}-6.779 * * \\
(3.343)\end{array}$ & $\begin{array}{c}-27.136 * * * \\
(9.559)\end{array}$ \\
\hline Summary box & $\begin{array}{l}-2.429 \\
(3.361)\end{array}$ & $\begin{array}{l}-2.820 \\
(3.333)\end{array}$ & $\begin{array}{l}-13.262 \\
(9.485)\end{array}$ \\
\hline Opportunity & $\begin{array}{l}-4.130 \\
(3.361)\end{array}$ & $\begin{array}{l}-4.168 \\
(3.326)\end{array}$ & $\begin{array}{l}-10.220 \\
(9.525)\end{array}$ \\
\hline Collective Omission to Commission & $\begin{array}{c}-22.406^{* * *} \\
(3.285)\end{array}$ & $\begin{array}{c}-19.455^{* * *} \\
(3.276)\end{array}$ & $\begin{array}{c}-42.522 * * * \\
(9.298)\end{array}$ \\
\hline Individual Omission to Commission & $\begin{array}{c}-18.345 * * * \\
(3.442)\end{array}$ & $\begin{array}{c}-18.397 * * * \\
(3.402)\end{array}$ & $\begin{array}{c}-17.809 * \\
(9.616)\end{array}$ \\
\hline Income & & $\begin{array}{c}-0.003 * * * \\
(0.000)\end{array}$ & $\begin{array}{c}-0.003 * * * \\
(0.000)\end{array}$ \\
\hline Male & & $\begin{array}{c}39.765 * * * \\
(1.939)\end{array}$ & $\begin{array}{c}35.515 * * * \\
(5.026)\end{array}$ \\
\hline Reciprocity * Income & & & $\begin{array}{c}0.000 \\
(0.001)\end{array}$ \\
\hline Planning * Income & & & $\begin{array}{c}0.001 * * \\
(0.001)\end{array}$ \\
\hline Summary box * Income & & & $\begin{array}{c}0.001 \\
(0.001)\end{array}$ \\
\hline Opportunity * Income & & & $\begin{array}{c}0.000 \\
(0.001)\end{array}$ \\
\hline Collective Commission $*$ Income & & & $\begin{array}{c}0.001 * * \\
(0.001)\end{array}$ \\
\hline Individual Commission * Income & & & $\begin{array}{c}0.000 \\
(0.001)\end{array}$ \\
\hline Reciprocity * Male & & & $\begin{array}{l}-0.738 \\
(7.220)\end{array}$ \\
\hline Planning * Male & & & $\begin{array}{c}3.184 \\
(7.222)\end{array}$ \\
\hline Summary box * Male & & & $\begin{array}{l}-0.917 \\
(7.172)\end{array}$ \\
\hline Opportunity * Male & & & $\begin{array}{c}3.606 \\
(7.189)\end{array}$ \\
\hline Collective Commission * Male & & & $\begin{array}{c}15.002 * * \\
(7.052)\end{array}$ \\
\hline Individual Commission $*$ Male & & & $\begin{array}{c}7.698 \\
(7.309)\end{array}$ \\
\hline Constant & $\begin{array}{c}250.162 * * * \\
(2.367)\end{array}$ & $\begin{array}{c}282.875 * * * \\
(3.346)\end{array}$ & $\begin{array}{c}291.876^{* * * *} \\
(6.673) \\
\end{array}$ \\
\hline $\mathrm{N}$ & 38292 & 38097 & 38097 \\
\hline $\mathrm{R}^{2}$ & 0.002 & 0.02 & 0.02 \\
\hline
\end{tabular}

Notes: These OLS regressions use robust standard errors. The control group had a mean payment days to payment of 250.102 and a standard deviation of 174.222. Standard errors in parentheses. * $\mathrm{p}<0.05, * * \mathrm{p}<0.01, * * * \mathrm{p}<0.001$ 
Appendix: Control letter

Dear SirlMadam

Date of issue 25 April 2012

Regrence REF ERENCE NUMBER

Your Tax Credits debt of $£ 999999999999.99$

We told you recently that you were paid too m uch through your tax credits. Our records show you have not been in touch about this.

\section{Please call 08453021421 now.}

Calling us is quick and easy, and you can spread your paym ent over 12 months.

You can pay by debit card, credit card or Direct Debit. You can also pay using internet and telephone banking. For more in formation on how to pay, go to www.hmrc.gov.ukjpayinghrrc.

If you believe that you don't ove this am ount, please call us on the num ber above.

If you have already paid, thank you. If not, please ad now.

Yours faithfully

Officer of Revenue and Customs

ID MSg9P

HMR C $10 / 10$ 
Example trial letter - Collective Omission to Commission

Dear Sir/Madam

Date of issue 25 April 2012

Reference REFERENCE NUMBER

Your Tax Credits debt of £999999999999.99

We told you recently that you were paid too much through your tax credits. Our records show you have not been in touch about this.

Previously, we treated your lack of response as an oversight. Now, if you do not call 08453021421 , we will treat this as an active choice.

Calling us is quick and easy, and you can spread your payment over 12 months.

You can pay by debit card, credit card or Direct Debit. You can also pay using internet and telephone banking. For more information on how to pay, go to www.hmrc.gov.uk/payinghmrc .

If you believe that you don't owe this amount, please call us on the number above.

If you have already paid, thank you. If not, please act now.

Yours faithfully

Officer of Revenue and Customs

IDMS99P

HMRC $10 / 10$ 